\title{
SALVADOR CIDADE DEFICIENTE: O ACESSO ÀS PRAIAS PARA PESSOAS COM DEFICIÊNCIA FÍSICA
}

\author{
Salvador city disabled: access to beaches for people with physical deficiency
}

Milton Silva de Vasconcellos (UNIFASS)

Informações do artigo

Recebido em 07/05/2019

Aceito em 12/05/2019

doi>: https://doi.org/10.25247/2447-861X.2019.n246.p196-226

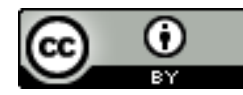

Esta obra está licenciada com uma Licença Creative Commons Atribuição 4.0 Internacional.

Como ser citado (modelo ABNT)

VASCONCELLOS, Milton Silva de. Salvador cidade deficiente: 0 acesso às praias para pessoas com deficiência física. Cadernos do CEAS: Revista Crítica de

Humanidades, Salvador, n. 246, jan./abr., p. 196-226, 2019. DOI: https://doi.org/10.25247/2447861X.2019.n246.p196-226

\begin{abstract}
Resumo
Este artigo analisa a acessibilidade para pessoas com deficiência física às praias da orla de Salvador que integram as mais recentes políticas públicas voltadas à urbanização da orla da cidade. Discutindo a questão da deficiência, adota-se o debate sobre a superação do modelo biomédico de deficiência para o modelo social, com vistas a se alcançar uma perspectiva de deficiência como um atributo da pessoa. Em sequência, analisam-se os aspectos principais das duas últimas políticas públicas voltadas à urbanização da orla de Salvador, realizadas pelo Estado e Município, aferindo, em sequência, o nível de acessibilidade de acesso das pessoas com deficiência física a esses espaços, tendo como parâmetro os critérios previstos pela norma técnica de acessibilidade a equipamentos urbanos NBR 9050, além da realização de entrevistas e observação direta. Como resultado encontrado, identificou-se a realidade de falta de acessibilidade para pessoas com deficiência física às praias de Salvador, traduzido pela presença de poucos equipamentos públicos existentes com efetiva utilidade para viabilizar a acessibilidade nestes locais, expressando, assim, uma acessibilidade meramente formal, bem como uma percepção diferente sobre "frequentar as praias" por estas pessoas, consolidando, assim, o fenômeno do "usuário televisão de cachorro".
\end{abstract}

Palavras-chave: Pessoa com deficiência física. Acesso às praias. Acessibilidade. Salvador.

\section{Abstract}

This article analyzes the accessibility for people with physical disabilities to the beaches of the border of Salvador that integrate the most recent public policies directed to the urbanization of the edge of the city. Discussing the issue of disability, the debate about overcoming the biomedical model of disability for the social model is adopted, aiming at achieving a disability perspective as an attribute of the individual. The main aspects of the last two public policies aimed at the urbanization of the border of Salvador, carried out by the State and Municipality, are analyzed in sequence, assessing, in a sequence, the level of accessibility of people with physical disabilities to these spaces, parameter criteria foreseen by the technical standard for accessibility to urban equipment NBR 9050, in addition to conducting interviews and direct observation. As a result, it was identified the reality of lack of accessibility for people with physical disabilities on the beaches of Salvador, reflected by the presence of few existing public facilities with effective utility to make accessibility possible in these places, thus expressing a merely formal accessibility, as well as a different perception about "attending the beaches" by these people, thus consolidating the "dog television user" phenomenon.

Keywords: Person with physical disability. Access to beaches. Accessibility. Salvador. 


\section{Introdução}

Este artigo discute a acessibilidade de Pessoas com Deficiência (PcD) às praias da orla de Salvador, mais especificadamente no que tange à deficiência física e às nove praias que integram as duas políticas públicas mais recentes voltadas à urbanização da orla da cidade, quais sejam: o Projeto Municipal de Revitalização da Orla, que atingiu as praias da Barra, Boca do Rio, Itapuã, Jardim de Alá, Paripe, Piatã, Ribeira, Rio Vermelho e Tubarão e o Plano Estadual de Requalificação da Orla de Salvador, que contemplou as praias da Amaralina, Pituba e Jardim dos Namorados.

De acordo com a Pesquisa Nacional de Saúde (PNS) - realizada pelo Instituto Brasileiro de Geografia e Estatística (IBGE, 2015), 6,2\% da população brasileira apresenta alguma deficiência física, sendo a segunda em números globais - superada apenas pelas PcD visual -, representando $1,3 \%$ da população brasileira, e quase a metade deste total (46,8\%) apresenta um grau intenso ou muito intenso de limitações. Logo, discute-se sobre um problema que atinge uma parcela significativa da população, cujo reconhecimento do acesso aos espaços públicos é reflexo da própria qualidade da cidadania da qual a sociedade atual é refratária.

Nesse sentido, a temática dos direitos de PCD extrapola as meras promessas legislativas para alcançar o status diferenciado com o advento de tratados internacionais sobre direitos humanos ${ }^{1}$, vinculando a atuação estatal a mais do que apenas elaborar leis. Nesse sentido é que, com vistas a se alcançar os resultados sobre o tema, delimita-se o objetivo geral de estudar o acesso às praias no município de Salvador por PCD física, bem como o problema de pesquisa a partir da seguinte indagação: de que forma foi desenvolvida a acessibilidade às praias contempladas pelas últimas políticas públicas voltadas à urbanização da orla do município de Salvador?

Para tanto, são considerados três objetivos específicos, os quais também nortearão a elaboração dos argumentos desenvolvidos e ajudarão, ao final, a responder o problema de pesquisa proposto:

${ }^{1}$ A exemplo da Convenção sobre os Direitos das Pessoas com Deficiência (2006). 
a) considerar as últimas políticas públicas voltadas à urbanização da orla de Salvador, realizadas pelo estado e município;

b) aferir os critérios estabelecidos pela Norma Brasileira (NBR) 9050 para a definição de acessibilidade em espaços púbicos externos, dentre os quais se inserem as praias;

c) analisar o nível de acessibilidade às nove praias que integram as duas políticas públicas mais recentes voltadas à urbanização da orla da cidade.

Sob o prisma metodológico, os instrumentos utilizados traduzem uma estratégia ampla, que passa pela revisão de literatura a respeito dos modelos teóricos sobre deficiência, bem como os conceitos de acessibilidade, políticas públicas e direito à cidade, buscando enfatizar a realidade do acesso a bens públicos por $\mathrm{PCD}$, em específico às praias do município de Salvador.

Além da revisão bibliográfica citada, foram realizados, a partir da observação direta e participante das praias contempladas pelas duas políticas públicas de urbanização da orla do município (totalizando 12 praias visitadas), registros fotográficos das doze praias estudadas e entrevistas com os protagonistas desta história: as PCD física.

O trabalho é desenvolvido em três partes, sendo que, na primeira delas, é abordada a questão da deficiência, seu tratamento pela literatura a partir da abordagem sobre dois modelos teóricos. Na segunda parte, reporta-se às duas últimas políticas públicas voltadas à urbanização da orla de Salvador, especificando suas peculiaridades e finalidades. Na terceira e última parte, são abordadas as condições de acessibilidade das 12 praias citadas, por meio de registros fotográficos resultantes da observação direta realizada nestes locais.

Como consequência da pesquisa realizada, concluiu-se que, apesar das últimas políticas públicas voltadas à urbanização da orla da cidade, realizadas pelo município de Salvador e o Governo do estado da Bahia, em pleno âmbito do paradigma do modelo social de deficiência, inexiste acessibilidade às praias para as pessoas com deficiência física no município de Salvador, limitando-se estas pessoas a uma acessibilidade meramente formal e ao fenômeno do "usuário televisão de cachorro".

\section{A questão da deficiência: modelos biomédico e social}

É fato que, longe de ser uma anormalidade/imperfeição, a deficiência é parte da condição e experiência humana. Contudo, tal percepção nem sempre foi assim, sendo, 
inicialmente, compreendida como uma disfunção do corpo (modelo biomédico), até ser entendida como uma peculiaridade do corpo da pessoa, um atributo normal do indivíduo (modelo social) com reflexos diretos para a responsabilidade estatal na formulação de políticas públicas.

Daí o porquê de se falar no conceito de deficiência como uma construção histórica, pois, uma vez que o sentido da concepção de deficiência altera com o tempo e ganha matizes distintas, a depender do olhar (científico) que se estabeleça, naturalmente que os valores culturais, historicamente localizados, permitem a identificação de pessoas estigmatizadas em função da deficiência e do contexto histórico em que se insiram.

Por tal motivo, Ribas (1985) sugere que a compreensão sobre os padrões em que se expressa a diferença numa sociedade só podem ser estudados em função do contexto histórico em que se insiram.

Nesse sentido, desde a Antiguidade é possível identificar percepções sobre a deficiência que a associam desde a um castigo divino até a um atributo de divindades. Por tal razão, ao se referir à Grécia antiga, Carvalho-Freitas (2007, p. 39) alude à mitologia para indicar referências às $\mathrm{PcD}$ :

O mito que melhor retrata o tratamento destinado às pessoas com deficiência na mitologia grega é o de Hefestos, deus do fogo, que doma os metais e torna possíveis as artes. Seu correlato na mitologia romana é o de Vulcano. Hefestos, filho de Zeus e de Hera, além de fisicamente bruto, era coxo. Contudo, só se pode compreender o mito de Hefestos quando se retomam as relações estabelecidas por ele, sua história e seu destino.

Nesse contexto e para Carvalho-Freitas (2007), a percepção trazida pela mitologia reforça a concepção de homem necessária à organização de uma sociedade guerreira, agrícola e preocupada com a defesa e subsistência da organização social que aspirava ao homem "belo e bom". Por tal motivo, justifica-se a concepção negativa da deficiência como um empecilho à sobrevivência/subsistência do povo, bem como impeditiva para o trabalho ou a guerra.

Ao superar essa fase e tomando-se a Idade Média como parâmetro, destaca-se a prevalência da Igreja, motivando uma compreensão que faz da deficiência um fenômeno espiritual (CARVALHO-FREITAS: 2007).

Nesse contexto histórico, e atrelando-se à superstição, Carvalho-Freitas (2007) pondera acerca de uma percepção de deficiência associada a variantes espirituais, ora sendo 
compreendida como eleição divina, ora como castigo de Deus ou possessão diabólica. Nesse período, além do recolhimento aos conventos ou igrejas, com o advento da Inquisição, toda PcD que fosse reconhecida por ser uma encarnação do mal (pecado) era destinada à tortura e à fogueira.

Com a Idade Moderna e o advento do lluminismo - e a consequente superação do paradigma conhecido como "idade das trevas" -, vem à tona o Racionalismo e o afastamento das visões supersticiosas sobre deficiência. Nesse sentido, o advento de padrões tidos como "normais" para o ser humano - tendo como esteio o incipiente pensamento racional da época -, é que marca uma transição entre a superstição e o conhecimento científico (PESSOTI, 1984 apud CARVALHO-FREITAS, 2007).

O que se depreende desse período é a mudança de status das pessoas com deficiência: de vítimas de um poder sobrenatural para o de 'desviantes' ou doentes, sendo a matriz de interpretação predominante sobre a deficiência os critérios de normalidade definidos pela medicina. (CARVALHO-FREITAS, 2007, p. 51, grifo do autor).

Tal compreensão será o pano de fundo para o modelo biomédico de deficiência e refratário de uma visão mecanicista do mundo que iria se espalhar por todas as áreas do conhecimento, justificando a análise da deficiência enquanto patologia (oriunda do modelo biomédico de deficiência) que iria prevalecer por todo o Século XX seguinte (AMIRALIAN et al, 2000).

Em linhas gerais, e considerando-se os períodos históricos, a evolução da concepção da deficiência emerge desde algo negativo - na Idade Antiga -, passando por uma percepção atrelada à superstição, na qual a deficiência era concebida como um castigo divino - na Idade Média -, tendo sido superada pelo racionalismo, em que a deficiência era valorada a partir de uma comparação de um padrão "normal" para o ser o humano - na Idade Moderna -, até alcançar a atual concepção, na qual a deficiência é compreendida como um atributo do indivíduo, uma característica deste - na Idade Contemporânea -, cuja abordagem pode ser visualizada a partir do Quadro 1 a seguir:

Quadro 1-Concepções de deficiência por período histórico

\begin{tabular}{|l|l|l|}
\hline \multicolumn{1}{|c|}{ Período histórico } & \multicolumn{1}{|c|}{ Concepção } & \multicolumn{1}{|c|}{ Reflexos dessa concepção } \\
\hline Idade Antiga (Grécia) & $\begin{array}{l}\text { Deficiência associada a um castigo } \\
\text { divino ou à virtude de divindades. }\end{array}$ & $\begin{array}{l}\text { A deficiência concebida como algo } \\
\text { negativo. }\end{array}$ \\
\hline Idade Média & $\begin{array}{l}\text { Deficiência enquanto fenômeno } \\
\text { espiritual. }\end{array}$ & $\begin{array}{l}\text { Deficiência como um castigo divino ou } \\
\text { possessão diabólica. }\end{array}$ \\
\hline Idade Moderna & $\begin{array}{l}\text { Racionalismo e o afastamento das } \\
\text { visões supersticiosas sobre deficiência. }\end{array}$ & $\begin{array}{l}\text { Tentativa de tratamento da deficiência } \\
\text { a partir de uma adequação ao padrão }\end{array}$ \\
\hline
\end{tabular}




\begin{tabular}{|l|l|l|}
\hline & & $\begin{array}{l}\text { tido como "normal" para o ser } \\
\text { humano. }\end{array}$ \\
\hline Idade Contemporânea $^{2}$ & Modelo biomédico. & $\begin{array}{l}\text { Deficiência enquanto estado de } \\
\text { patologia. }\end{array}$ \\
\hline Idade Contemporânea $^{3}$ & Modelo social. & $\begin{array}{l}\text { Deficiência como um atributo do } \\
\text { indivíduo, uma característica deste. }\end{array}$ \\
\hline
\end{tabular}

Fonte: adaptado de Carvalho-Freitas (2007)

A compreensão da deficiência trazida pela Idade Contemporânea e enquanto fato social - bem como o desenvolvimento das políticas públicas no Brasil, voltadas a esta temática -, exige uma abordagem dos dois modelos que viriam prevalecer nos Séculos XX e XXI, respectivamente, o modelo biomédico e o modelo social de deficiência.

Discorrendo acerca do primeiro modelo citado e remontando aos fins do Século XX (1976), por meio de documentos da Organização Mundial de Saúde (OMS apud DINIZ, 2007), a compreensão da deficiência enquanto estado de patologia (modelo biomédico) concretiza a definição desta realidade como algo relacionado a uma anomalia de estrutura/aspecto físico ou função psicológica.

Neste período, como continuação da adoção do critério de "normalidade" do ser humano surgem, como consequência da influência do racionalismo - na Idade Moderna -, tratamentos médicos em instituições psiquiátricas ${ }^{4}$ em que, além da segregação, reitera-se uma visão exoneratória do Estado (DINIZ, 2007).

A autora destaca que a deficiência passou, então, a ser compreendida como uma consequência natural de lesão ao corpo, sendo que o indivíduo portador de tais atributos é visto não como um sujeito de direitos, mas como um objeto de cuidados médicos, justificando a exoneração de responsabilidade estatal, cujas ações - quando existentes -, possuem natureza que mais se aproximam da caridade do que propriamente de uma política pública, agravando ainda mais o alijamento e a exclusão destas pessoas.

Acerca do tema, Diniz (2007) pondera que, em 1980, com a publicação pela OMS de um catálogo oficial de lesões e deficiências, surge a Classificação Internacional de Lesão, Deficiência e Handcap - International Classification of Impairments, Disabilities, and Handicaps

2 Século $X X$.

3 Fins do Século XX e Século XXI.

4 Ao tratar das instituições psiquiátricas, a literatura refere-se às PcD intelectual, não se aplicando às PcD física, porém, isso em nada altera a segregação, pois o paradigma exoneratório alcança a todas as $P c D$, inclusive as com deficiência física, no contexto do modelo biomédico de deficiência. 
(ICIDH), criando, assim, uma catalogação similar à já existente para as doenças - a Classificação Internacional de Doenças (CID) -, em que as lesões e deficiências seriam compreendidas. Mais do que simplificar o tema, a intenção era padronizar a terminologia internacional para fins de elaboração de políticas de saúde voltadas a esta área. Para esta linha de pensamento, deficiência seria a:

[...] perda ou anormalidade de estrutura ou função psicológica, fisiológica ou anatômica, temporária ou permanente. Incluem-se nessas a ocorrência de uma anomalia, defeito ou perda de um membro, órgão, tecido ou qualquer outra estrutura do corpo, inclusive das funções mentais. Representa a exteriorização de um estado patológico, refletindo um distúrbio orgânico, uma perturbação no órgão. (AMIRALIAN et al, 2000, p. 98).

Em resposta a esta realidade e à absurda exoneração de responsabilidade estatal para com estas pessoas - haja vista ser a deficiência considerada como um problema do indivíduo -, constata-se o surgimento de visões contrárias, exigindo-se a responsabilidade da sociedade para com estas pessoas, mudando suas estruturas de forma a propiciar a inclusão.

Do conjunto destes argumentos, seria suscitada uma nova perspectiva na compreensão da deficiência, não mais passível de compreensão como uma doença ou problema do próprio indivíduo, mas sim, uma noção de forte inspiração no materialismo histórico, no qual a deficiência é percebida como um atributo do corpo do indivíduo, sendo toda forma de não aceitação destes atributos uma forma de opressão da sociedade, surgindo, assim, o modelo social de deficiência, como discute Diniz (2007). Acerca do tema, discorre a doutrina que:

Os corpos com impedimentos seriam inúteis à lógica produtiva em uma estrutura econômica pouco sensível à diversidade. Já o modelo biomédico afirmava que a experiência de segregação, desemprego, baixa escolaridade, entre tantas outras variações da desigualdade, era causada pela inabilidade do corpo com impedimentos para o trabalho produtivo. Hoje, a centralidade no materialismo histórico e na crítica ao capitalismo é considerada insuficiente para explicar os desafios impostos pela deficiência em ambientes com barreiras, mas se reconhece a originalidade desse primeiro movimento de distanciamento dos corpos com impedimentos dos saberes biomédicos (CORKER; SHAKESPEARE, 2002, p. 3 apud DINIZ, 2007, p. 23).

Prevalecente em todo o Século $X X$, o modelo biomédico de deficiência irá se refletir na gradativa elaboração de políticas públicas voltadas a esta temática, sempre 
condicionando as poucas ações previstas em lei a uma adequação/ enquadramento do indivíduo a um catálogo prévio de doenças. ${ }^{5}$

Superando a perspectiva do modelo biomédico de deficiência, o conhecido modelo social da deficiência emerge na Inglaterra no final da década de 1970, superando-se a visão excludente e que tratava a deficiência como um problema do indivíduo. Constata-se, pois, uma compreensão inclusiva, em que a noção de exclusão destas pessoas resta inadmissível, por força de barreiras, gerando não apenas o esgotamento do paradigma anterior (modelo biomédico de deficiência), como, também, o surgimento de uma nova compreensão, fruto de uma visão que relaciona a deficiência ao meio ambiente (COHEN, 2006). Nesse sentido, Rieser (1995, p. 55-56 apud AMIRALIAN et al, 2000, p. 100):

[...] analisou as diferenças entre o modelo médico e o social de incapacidade. Apontou que: o modelo médico enfatiza a dependência, considerando a pessoa incapacitada como um problema, e o modelo social atribui as desvantagens individuais e coletivas das pessoas com deficiência principalmente à discriminação institucional. Sugeriu que a solução para a incapacidade estaria na reestruturação da sociedade.

Por tal razão, para Cohen (2000, p. 25), a deficiência é um conceito que pode variar em um sentido cultural, social e até mesmo ambiental:

A deficiência pode ser uma situação que faz parte de um contexto cultural, social e ambiental das pessoas que a possuem. Também pode ser vista como um aspecto especial que oferece novas oportunidades para a experiência e o amadurecimento do nosso sujeito no mundo. Posturas corporais, competências motoras e motricidades específicas podem revelar pontos de vista mais de acordo com uma nova ordem que libere o tratamento do corpo deficiente dos modelos de um padrão idealizado.

Tal perspectiva também se projeta no campo da responsabilidade pública, forçando as responsabilidades do Estado e da sociedade para com a inclusão destas pessoas. Nesse contexto mais amplo, a deficiência deixa de ser um problema e passa a ser compreendida como um atributo do indivíduo, uma característica deste, razão pela qual a noção de

\footnotetext{
5 Nesse sentido, ao prever a reserva de vagas em concursos públicos em empresas com mais de 100 funcionários, no art. 4, o Decreto n. 3.298, de 20 de dezembro de 1999, define deficiência física como a "[...] alteração completa ou parcial de um ou mais segmentos do corpo humano, acarretando o comprometimento da função física, apresentando-se sob a forma de paraplegia, paraparesia, monoplegia, monoparesia, tetraplegia, tetraparesia, triplegia, triparesia, hemiplegia, hemiparesia, ostomia, amputação ou ausência de membro, paralisia cerebral, nanismo, membros com deformidade congênita ou adquirida, exceto as deformidades estéticas e as que não produzam dificuldades para o desempenho de funções." (BRASIL, 1999). Logo, aquele que não se encaixa nessas definições (catalogação) fica automaticamente excluído das políticas públicas que esta norma veicula.
} 
"acessibilidade", bem como a superação das "barreiras" trazidas pela legislação, convertem a um fim comum: a inclusão social.

\section{Políticas públicas voltadas à urbanização da Orla de Salvador}

Considerando sua faixa litorânea, tanto o texto legal, bem como a bibliografia consultada, refere-se à orla marítima, como uma franja (borda) de largura variável, de contato imediato entre terra e mar, com limites legalmente estabelecidos (SOUZA, 2017, p. 88).

Quanto a este tema, o município de Salvador, a partir do Plano Diretor de Desenvolvimento Urbano (PDDU-2016), em seu art. 272, trata desta área como inserta na Área de Borda Marítima (ABM), cuja definição é estabelecida pela norma citada nos seguintes termos:

Art. 272 -A ABM é a faixa de terra de contato com o mar, compreendida entre as águas e os limites por trás da primeira linha de colinas ou maciços topográficos que se postam no continente, em que é definida a silhueta da Cidade.(SALVADOR: 2016)

Valendo-se da nomenclatura "borda litorânea", Muñoz (2014, p. 87) define esta expressão como a "linha convencional, que marca o contato entre a terra e o mar [...]. Ajudando, assim, a determinar os limites de grande interesse para a gestão pública".

A considerar a orla do município de Salvador, Souza (2017, p. 33) aponta a existência de três faces: a faixa da orla atlântica, a faixa da orla da Baia de Todos os Santos e a faixa da orla insular, dentre as quais será considerada a porção da orla da Baía de Todos os Santos (BTS), por meio das dezessete praias que a integram: 
Figura 01 - Município de Salvador: Praias da Baía de Todos os Santos (BTS)

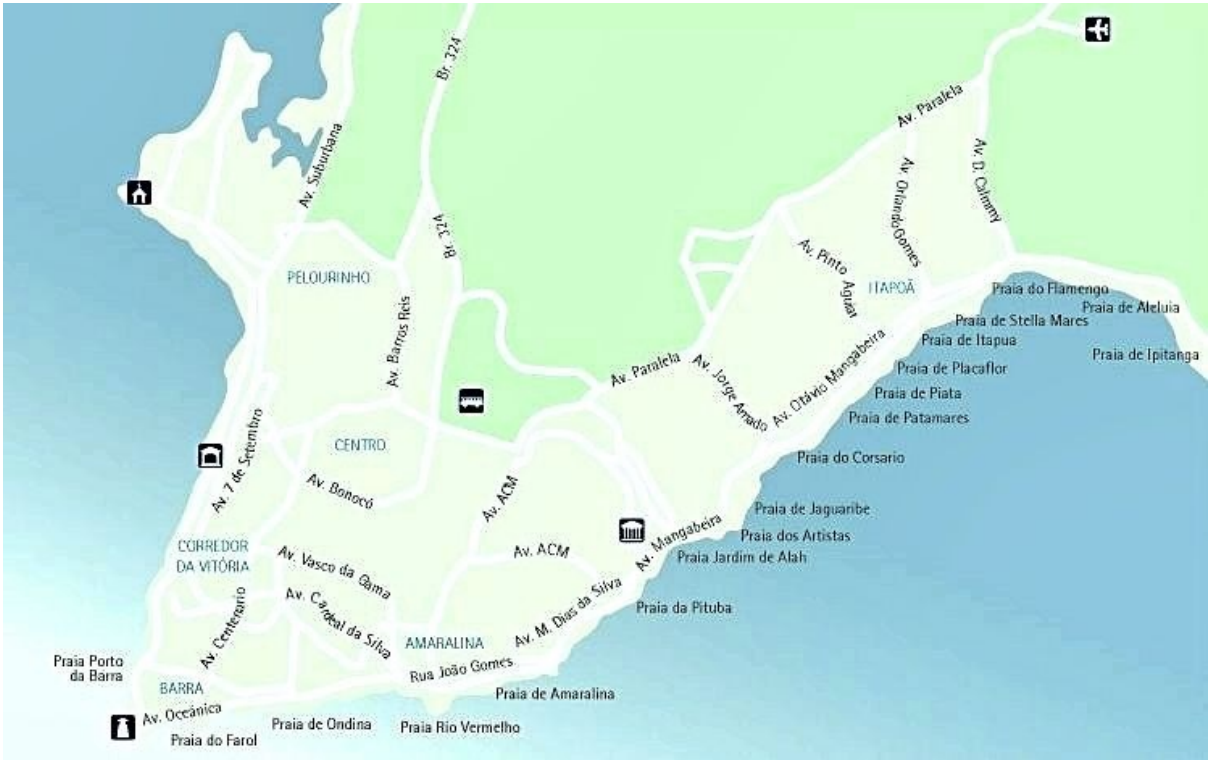

Fonte: http://www.viagemdeferias.com/salvador/praias/salvador.php

Consultando o histórico das políticas públicas realizadas por Estado e Município, voltadas à orla de Salvador, Souza (2017, p. 223) destaca oito intervenções voltadas à urbanização, contudo, para fins de interesse da presente pesquisa, serão consideradas, em síntese, apenas as mais recentes feitas pelo Estado e Município.

A citar a política pública estadual, o Projeto de Requalificação da Orla Atlântica de Salvador é criado em 2013, na gestão do então governador Jaques Wagner, sendo dividido em três etapas, prevendo-se, além de reparos da infraestrutura em trechos da orla, também a recuperação de calçadões e encostas afetados pela ação das marés, a requalificação de passeios e parte da balaustrada, com inserção de dispositivos de acessibilidade (CONDER, 2013).

Na primeira etapa do projeto, as obras previam intervenções no trecho da orla entre o Largo das Baianas (Amaralina) até o Jardim de Alah, com criação de uma praça integrada ao calçadão, além de implantação de jardins, arborização, quiosques e infraestrutura de estacionamento. (FONSECA, 2006, p. 17)

Segundo Souza (2017, p. 165), nesta etapa as ações de intervenção totalizaram um trecho de 2,5 quilômetros, cujas ações estenderam-se para além da orla, com o alargamento da Ponte do Rio Camarajipe, com reflexos diretos para a orla do município: 
O projeto previa a requalificação de cerca de 2,5 quilômetros do trecho do Quartel de Amaralina até a Praça João Amaral, assim como os acessos às praias, reforma e ampliação do calçadão na orla da Pituba, a recuperação dos trechos do Jardim dos Namorados e do Jardim de Allah, o alargamento da ponte do Rio Camarajipe, aumentando uma faixa no sentido Itapuã e a implantação de ciclovia. Além disso, foi realizada a modificação do traçado viário, a reforma das três quadras poliesportivas, nova balaustrada, instalação de mobiliário e equipamentos de apoio aos banhistas, reconstrução da sede da Colônia de Pesca, sinalização, paisagismo, drenagem e pavimentação, etc (SOUZA, 2017, p. 168)

Numa segunda etapa, as obras voltaram-se para o trecho entre o Quartel de Amaralina e o Largo das Baianas), sendo realizadas as mesmas intervenções: com criação de uma praça integrada ao calçadão, além da implantação de jardins, arborização, quiosques e infraestrutura de estacionamento, (FONSECA, 2006, p. 17)

Por fim, na terceira e última etapa, as obras voltaram ao trecho entre o Jardim de Alah até o antigo Aeroclube, com intervenções nas calçadas e encostas afetados pela ação das marés, além da colocação de dispositivos de acessibilidade (CONDER, 2013)

Neste sentido, as medidas de urbanização da orla, além de englobar a pavimentação, melhoria na iluminação, manutenção de ciclovia, estacionamento e criação de equipamentos de ginástica, previa a implantação de piso tátil para pessoa com deficiência visual, sendo esta a principal medida voltada à acessibilidade para pessoas com deficiência.

No âmbito municipal, a mais recente política pública voltada à urbanização da orla do município é o "Programa de Requalificação Urbano-Ambiental da Orla Marítima de Salvador", proposto pelo Município (gestão de Antônio Carlos Magalhães Neto), em 2013. Nesta política pública, intenta-se, em linhas gerais, intervenções de requalificação da Orla Atlântica e da Orla da Baía de Todos os Santos, por meio da instalação/manutenção de infraestrutura e equipamentos de lazer.

\section{A Cidade do Salvador e o acesso às praias: acessibilidade a partir da Norma Técnica 9050}

Salvador foi a primeira capital brasileira e tem uma população projetada de 2.857 .329 pessoas para o ano de 2018. Contando com um território de 692,818 quilômetros quadrados, o município apresenta 92,8\% dos domicílios com esgotamento sanitário adequado, 39,5\% de domicílios urbanos em vias públicas com arborização e 35\% de domicílios urbanos em vias públicas com urbanização adequada (presença de bueiro, calçada, pavimentação e meio-fio), segundo o Instituto Brasileiro de Geografia e Estatística (IBGE, 2017). 
Sob o aspecto histórico, a cidade de Salvador tem seu desenvolvimento influenciado diretamente pelas cidades do Recôncavo - região em torno da Baía de Todos os Santos formada pelos municípios de Cachoeira, São Félix, Santo Amaro e São Francisco do Conde , as quais desempenhavam uma importante influência na vida econômica da região. Nesse sentido, Carvalho e Pereira (2008, p. 83) apontam que:

Entre os anos 1940 e 1950, a cidade experimentou um crescimento demográfico causado, em parte, pelas migrações e, nesse período, a estrutura espacial de Salvador já se modificava em função de vários fatores, como a reestruturação do centro da cidade [...].

A cidade se desenvolve e experimenta a modernização da velha capital baiana, que deixa de ser uma região urbana pobre e incipiente, polarizada e praticamente estagnada, para dar oportunidade ao surgimento de uma rápida expansão urbana (entre as décadas de 1960 e 1970), com uma intensa ocupação informal de famílias de baixa renda, sobretudo nas periferias (CARVALHO; PEREIRA, 2008).

O novo centro urbano da cidade se consolidou na década de 1980, influenciado, sobretudo, pelos empreendimentos públicos e privados realizados na década anterior, o que terminou por gerar um novo direcionamento do crescimento da cidade para o sentido da orla Norte, consolidando uma nova estrutura de ocupação do espaço urbano na cidade, com destaque para três áreas distintas de expansão: a Orla Marítima Norte, o "miolo" e o Subúrbio Ferroviário. ${ }^{6}$ A Orla Marítima Norte é considerada como o reflexo da "área nobre" da cidade, local onde se concentram a riqueza e os investimentos públicos, com melhor estrutura e oportunidades de moradia, serviços e lazer.

A segunda área - denominada como "miolo" -, é reflexo da ocupação de população proveniente da classe média baixa, caracterizada por loteamentos populares e pela prestação de serviços e equipamentos públicos bastante restritos. Por fim, a terceira área - Subúrbio Ferroviário -, é reflexo da carência de infraestrutura, de serviços básicos e da precariedade

6 Não à toa, esta é a mesma divisão da prestação do serviço de ônibus na cidade, no qual as concessionárias exploram o serviço em três linhas, segundo dados oferecidos pela Secretaria de Mobilidade do Município (SEMOB, 2018): a) área da orla (Praça da Sé até Itapuã), explorada pela Integra Salvador Norte com 844 veículos, dentre os quais 739 são acessíveis; b) área do "miolo" (Mussurunga a Pernambués, incluindo Cajazeiras e Pau da Lima), explorada pela Ótima Transportes de Salvador SPE Sociedade Anônima (S/A), com uma frota de 932 veículos, dentre os quais 890 são acessíveis; e c) área do Subúrbio (São Tomé de Paripe ao Comércio), explorada pela empresa Plataforma Transportes SPE S/A, com uma frota de 777 veículos, dentre os quais 719 são acessíveis. 
habitacional, sendo ocupada por uma população extremamente pobre e, muitas vezes, vítima de altos índices de violência (CARVALHO; PEREIRA, 2008).

Com essa disposição é que os autores vão analisar o surgimento da moderna cidade de Salvador, fruto da apropriação diferenciada do território urbano. Nesse contexto, a divisão da cidade em três áreas de expansão - sendo uma mais rica e desenvolvida, com melhor infraestrutura e equipamentos urbanos (região da orla); outra mais precarizada, com acesso restrito a equipamentos urbanos (região do miolo); e uma terceira, ainda mais precarizada, com restrição ainda maior a equipamentos urbanos (região do Subúrbio) -, evidencia uma cidade marcada pela pobreza e por problemas de mobilidade.

Tais aspectos se relacionam com o acesso às praias para uma parcela de sua população ainda mais vulnerabilizada - as PcD física -, constatando-se que, apesar das últimas políticas públicas de urbanização realizadas pelo estado e município, em nada se alterou a realidade quanto à acessibilidade para as PCD física.

Seguindo o rigor trazido pela literatura, orienta-se a percepção da rota acessível para fins de se identificar a acessibilidade às praias a partir de três elementos: a) transportes públicos; b) piso de calçada, passeio e faixas livres e c) rebaixamento das calçadas.

Acerca do primeiro item - transportes públicos -, apesar de não ser expressamente citado pela NBR 9050 como requisito da rota acessível7, sua indicação se mostra importante, pois sua aferição configura um importante elemento para a configuração de mobilidade, sobretudo quando se considera que a maior parte das PCD física faz uso deste meio de transporte quando se dirige às praias, conforme constatamos na pesquisa de opinião realizada com 100 PCD física integrantes da ABADEF entre os meses de junho e setembro de 2018:

\footnotetext{
7 A compreensão deste item como integrante da rota acessível é depreendida de forma indireta quando a norma se refere a estacionamentos e faixas de travessias de pedestres, ou, ainda, pela expressão "dentre outros", citada expressamente no final da norma.
} 
Figura 2 - Gráfico das respostas da pesquisa de opinião envolvendo PcD física e o meio de deslocamento utilizado para a ida às praias de Salvador

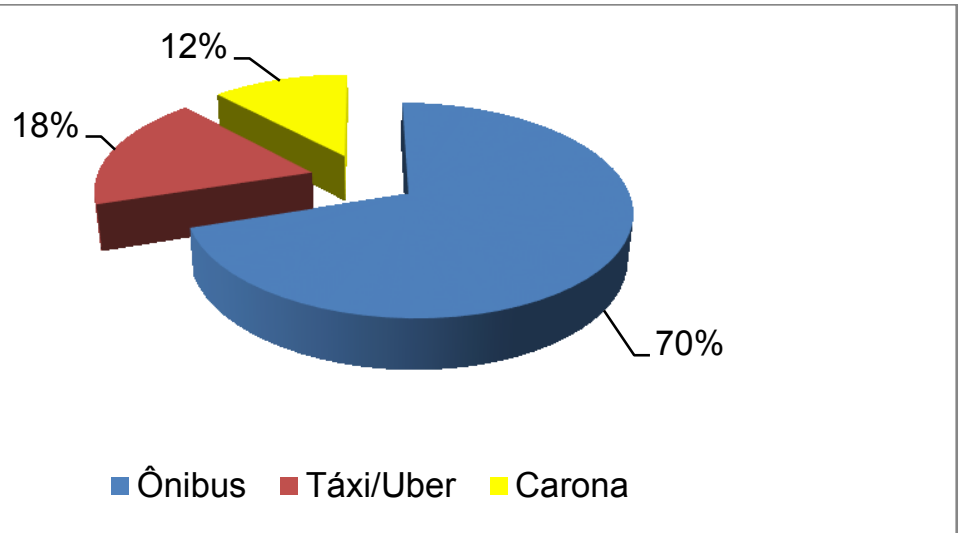

Fonte: pesquisa de campo.

Estes dados indicam um percentual de $70 \%$ das pessoas pesquisadas que utilizam ônibus como meio de deslocamento, desdobrando-se, como consequência, a importância da valoração do item "transportes públicos" na composição da rota acessível.

Nesse sentido, valorando o item "transportes públicos", a NBR 9050 traz critérios específicos sobre os abrigos em pontos de embarque e desembarque de transporte coletivo, conforme sua seção 8.2.1, os quais devem estar em condições gerais acessíveis e possuir assentos fixos para descanso e espaço para cadeiras de rodas, de forma que estas pessoas os cadeirantes - possam estacionar sem obstruir e interferir na livre circulação (ABNT, 2015).

Desta valoração, afere-se o "módulo de referência", aqui considerado o espaço reservado nos abrigos de ônibus, ao lado dos assentos para os usuários o qual, segundo a NBR 9050, deve ter no mínimo 80 centímetros $(\mathrm{cm})$ de largura por 1,20 metro $(\mathrm{m})$ de extensão e se posicionar ao lado dos assentos fixos, como indicado na Figura abaixo:

Figura 2 - Desenho do módulo de referência para abrigos de ônibus

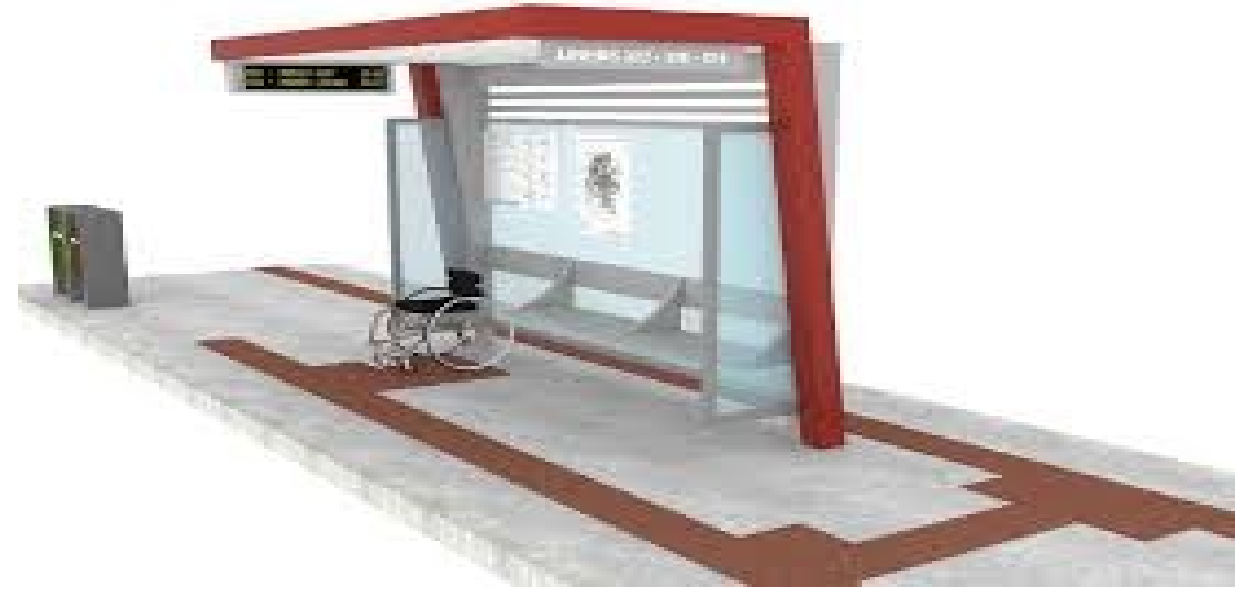

Fonte: Prefeitura Municipal de Londrina (2015, p. 1). 
Aferindo-se a realidade concreta de Salvador, por meio da observação direta realizada, foi possível verificar a existência destes módulos de referência em todas as 12 praias visitadas, excepcionando-se apenas a praia de Tubarão. Apesar disso, não existe nenhum tipo de sinalização que comunique tais módulos de referência ao piso, fazendo com que, ocasionalmente, estes espaços sejam ocupados por pessoas ou objetos, visto que são confundidos, pelos demais usuários, como espaços para carga ou algo similar.

A partir do trabalho da observação direta realizada em 12 praias visitadas, bem como aplicando, como parâmetro, o critério da existência do módulo de referência em abrigos de ônibus, pode-se ter a seguinte visão geral, organizada no Quadro abaixo:

Quadro 2 - Disponibilidade de abrigo de ônibus (com módulo de referência) nas praias de Salvador

\begin{tabular}{|l|c|c|}
\hline \multirow{2}{*}{ Praia } & \multicolumn{2}{|c|}{ Abrigo para ônibus com módulo de referência } \\
\cline { 2 - 3 } & Disponivel & Indisponivel \\
\hline Barra & $\mathrm{X}$ & \\
\hline Rio Vermelho & $\mathrm{X}$ & \\
\hline Amaralina & $\mathrm{X}$ & \\
\hline Pituba & $\mathrm{X}$ & \\
\hline Jardim dos Namorados & $\mathrm{X}$ & \\
\hline Jardim de Alá & $\mathrm{X}$ & \\
\hline Armação & $\mathrm{X}$ & \\
\hline Piatã & $\mathrm{X}$ & \\
\hline Itapuã & $\mathrm{X}$ & \\
\hline Ribeira & $\mathrm{X}$ & \\
\hline São Tomé & & $\mathrm{X}$ \\
\hline Tubarão & & \\
\hline
\end{tabular}

Fonte: pesquisa de campo.

Depreende-se que, em quase todas as praias visitadas, existe abrigo de ônibus com espaço reservado para cadeira de $\operatorname{rodas}^{8}$ (módulo de referência) ao lado dos assentos fixos, seguindo um padrão de construção nas principais praias da orla de Salvador. ${ }^{9}$

8 Em algumas praias, foi observada a coexistência de abrigos de ônibus mais novos e outros mais antigos, como nas praias do Subúrbio de Salvador, além do fato de não serem encontrados tais módulos de referência na praia de Tubarão, considerando-se os trechos da praia submetidos às obras de revitalização.

9 A existência do módulo de referência nos abrigos de ônibus em Salvador é, em verdade, um espaço existente ao lado dos assentos, feito em padrão pelas empresas Cemusa e JCDecaux, vencedoras da licitação realizada em 2000 (HORA DO BICO, 2018). 
A única praia em que o item é ausente está localizada no Subúrbio, inserida em uma zona mais pobre, onde as modernidades das demais praias da orla de Salvador (Cidade Alta) ainda não chegaram em sua completude. Nesse sentido, apesar de existirem pontos de ônibus nesta localidade, ainda prevalecem espaços adaptados e sem o formato dos demais pontos encontrados nas praias das áreas da orla e no "miolo" da cidade.

No segundo item considerado para valoração da rota acessível - piso da calçada, passeio e faixas livres -, a NBR 9050, em sua seção 6.1 indica a obrigatoriedade de os pisos apresentarem superfície regular, firme, estável e antiderrapante sob qualquer condição, de forma a não provocar trepidação em quaisquer dispositivos com rodas (cadeiras de rodas ou carrinhos de bebê). Admite-se, ao máximo, uma inclinação transversal da superfície em até $2 \%$ para pisos internos e $3 \%$ para pisos externos, com uma inclinação longitudinal máxima de $5 \%$ (ABNT, 2015).

A partir de tais especificações, resta clara a preocupação da norma com o critério de segurança, de forma que, durante o deslocamento, não existam obstáculos ou quaisquer outras irregularidades que dificultem a mobilidade de PcD. Uma vez que o acesso à praia não se restringe ao percurso da calçada à areia, mas sim, desde o domicílio da $P c D$, parece evidente que devam ser considerados os demais pisos do entorno à praia, verificando-se a eventual presença de irregularidades ou obstáculos a impedirem o livre deslocamento, sendo, assim, aferidas as calçadas, o passeio e as faixas livres.

Para Sousa Junior e Floro (2017), as calçadas devem apresentar três faixas a ser respeitadas: "faixa de serviço, faixa livre e faixa de acesso." Compreende-se a faixa de serviço como o trecho da calçada destinado à instalação de equipamentos urbanos pelo Estado e, por não se destinar à circulação de pessoas, pode ser instalado o maquinário de infraestrutura para a prestação de serviços públicos, tais como postes, equipamentos de sinalização de trânsito, bancos, árvores, abrigos para pontos de ônibus e hidrantes, além de obras voltadas à passagem subterrânea de tubulações.

A seu turno, a faixa livre tem sua definição trazida pela NBR 9050, como o trecho da calçada destinado - de forma exclusiva -, à circulação de pedestres. Nesta faixa é que ficariam as PcD que se deslocam por meio de cadeiras de rodas, na condição de pedestres (ABNT, 2015). Por fim, a faixa de acesso se refere ao trecho imediatamente posterior à faixa livre e que se liga diretamente aos imóveis. 
Dessa forma, para que se possa considerar como acessível a faixa da calçada destinada à circulação de pessoas (inclusive aquelas que se deslocam por meio de cadeiras de rodas), deve haver uma largura mínima de 1,20m, sendo admitidos obstáculos em apenas um trecho de $0,75 \mathrm{~m}$ (faixa de serviço).

Em termos práticos, quando avaliado o nível de acessibilidade nas praias, não raro encontram-se calçadas em que, em alguns trechos, há encurtamentos ou inserção de obstáculos (como cabines de banheiros químicos) para além da faixa de serviço da calçada, comprometendo a acessibilidade do local.

Por fim, o terceiro e último item de valoração da rota acessível citado são os rebaixamentos de calçadas que, segundo a NBR 9050, traz, na seção 6.12.3, devem, em síntese, apresentar uma largura conforme o fluxo de pedestres que transitam pelo local (ABNT, 2015).

Quanto à localização, estes equipamentos podem estar nas esquinas, nos meios de quadra ou nos canteiros divisores de pistas, conforme pode ser observado na Figura $4 \mathrm{a}$ seguir:

Figura 4-Desenho esquemático da vista superior de rebaixamentos de calçadas, segundo a NBR 9050

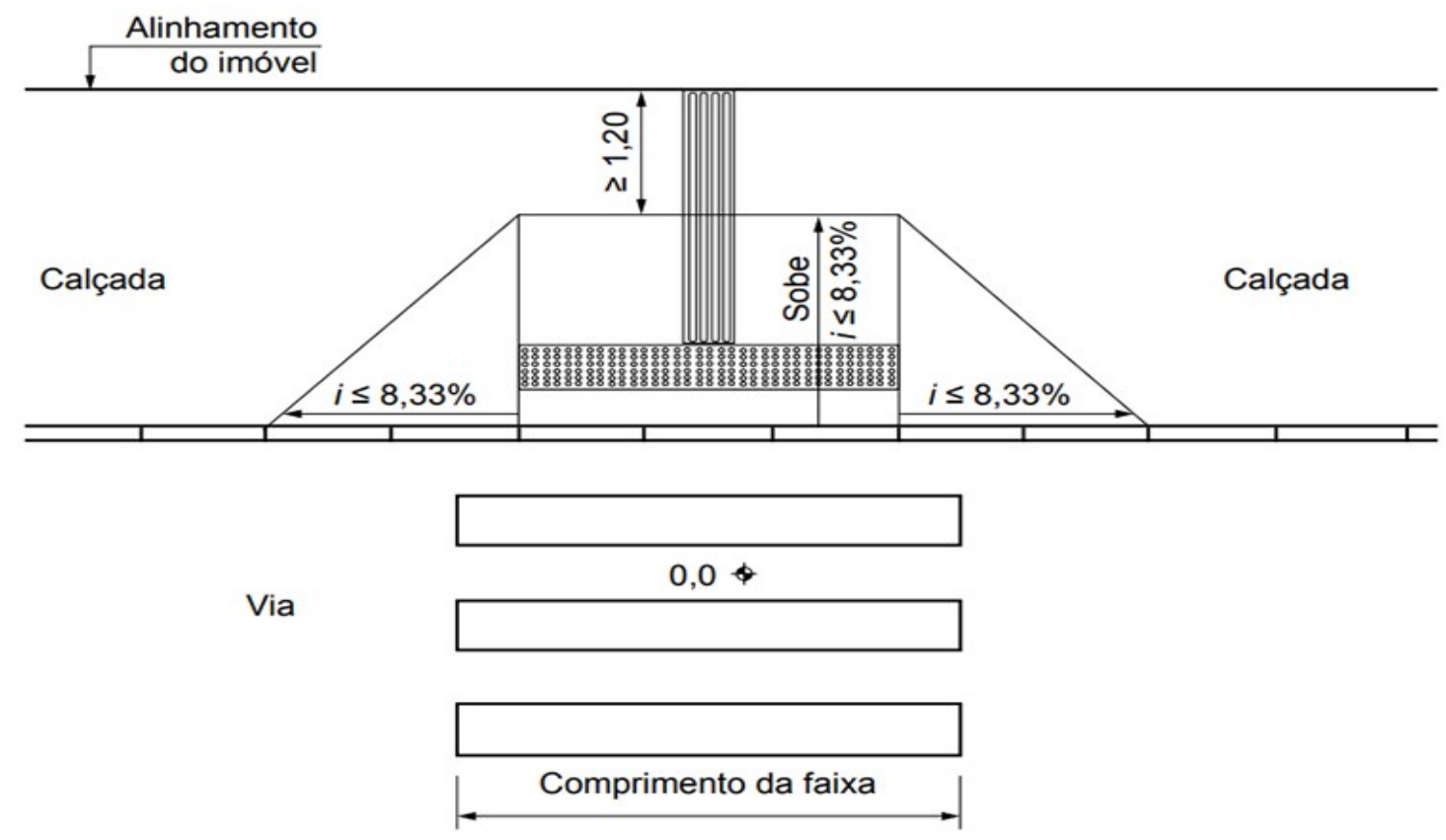

Fonte: $A B N T(2015$, p. 80).

Das 12 praias visitadas nesta pesquisa, foram identificados tais rebaixamentos de calçadas em quase todas, excepcionando-se, mais uma vez, a praia de Tubarão, o que leva a 
uma avaliação positiva (no sentido da disponibilidade destes equipamentos) nas principais praias da orla de Salvador.

\section{As condições de acessibilidade das Praias de Salvador}

Para a aferição do nível de acessibilidade e valendo-se dos critérios até então utilizados pela NBR 9050, foi mensurada a acessibilidade de cada uma das 12 praias visitadas a partir de quatro elementos: a) rampa para superar o desnível entre o passeio e a areia; b) piso fixo ou removível em direção ao mar; c) banheiros acessíveis e d) acessos devidamente sinalizados por meio do símbolo internacional de acesso.

Ao tratar do requisito rampa para superar o desnível entre o passeio e a areia, a seção 6.6.4.2 da NBR 9050 estabelece que, para pisos com até 3\% de inclinação, ou a cada 3om, as rampas devem apresentar uma área de descanso situada fora da faixa de circulação. Além destas especificidades, a norma recomenda que tais áreas de descanso devam possuir um espaço de tal de forma que se permita a manobra com cadeiras de rodas (BRASIL, 2015).

A partir destes parâmetros, para que possa ser considerada acessível, a rampa não deverá apenas obedecer à inclinação exigida, mas também dispor de uma área de descanso nas hipóteses de rampas mais longas, o que não foi encontrado em nenhuma das 12 praias visitadas. Para além de ser uma mera formalidade, o cumprimento destes critérios significa o parâmetro técnico de construção de equipamentos públicos seguros, viabilizando não apenas a utilização de maneira autônoma e segura do ambiente, edificações, mobiliário, equipamentos urbanos e elementos, mas, sobretudo, a humanização destes ambientes, à medida que passam a ser considerados acessíveis a todas as pessoas.

Entretanto, é forçoso notar que este parâmetro foi pensado para ambientes internos (como prédios), devendo ser extraído e adaptado para ambientes externos, como praias. Nesse sentido, serão guardadas as indicações referentes ao grau de inclinação, bem como à área de descanso (quando cabível), pois, para a realidade das praias de Salvador, as rampas não são muito longas, sobretudo as localizadas nas 12 praias avaliadas neste trabalho, como já informado alhures.

Em nenhuma das 12 praias visitadas foi observado o estrito cumprimento destes critérios técnicos, havendo, em alguns casos, situações em que foram aproveitadas rampas antigas para pescadores e que servem para o deslocamento de pessoas, tal como observado 
nas praias da Barra (Praia do Farol), do Rio Vermelho (trecho da Colônia de Pescadores) e Itapuã (trecho da Praia da Sereia).

Figura 5 - Fotografia da rampa de acesso de embarcações à praia do Rio Vermelho

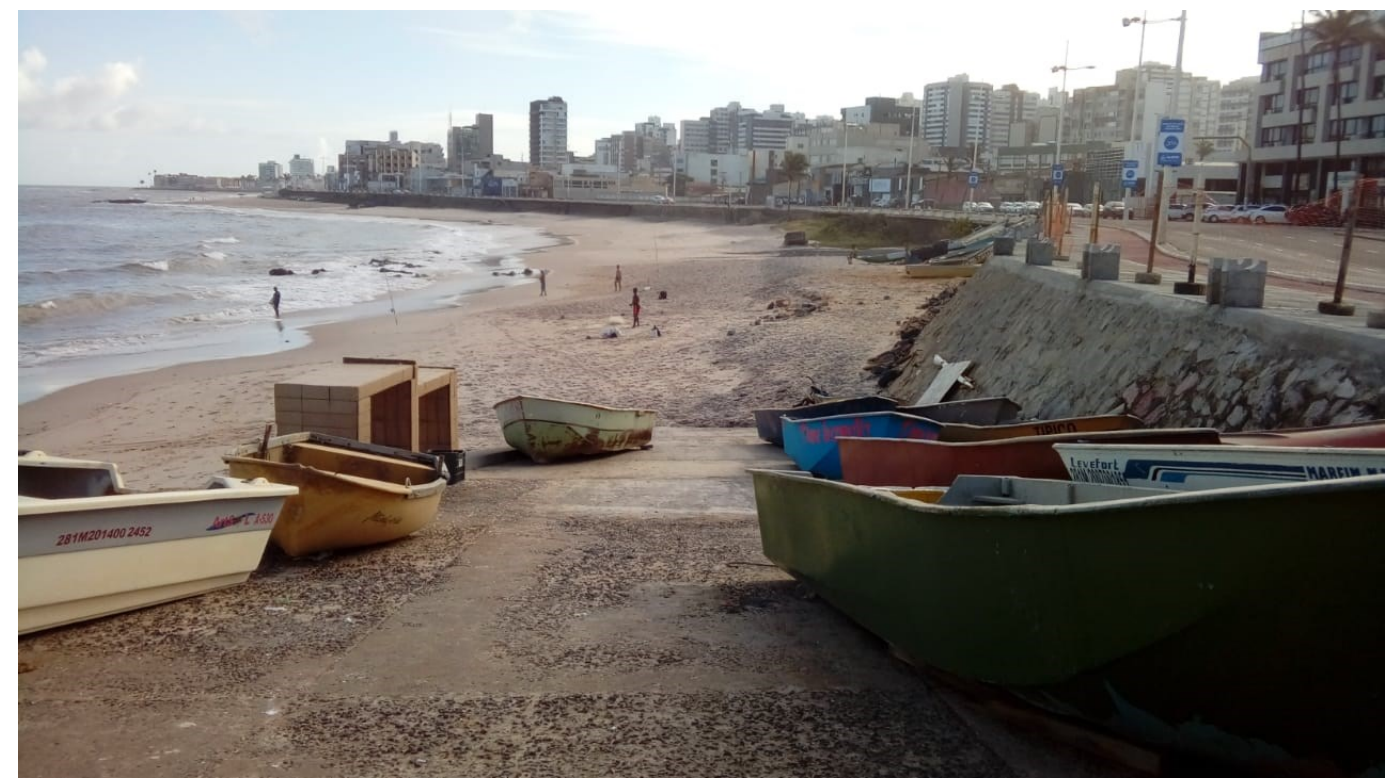

Fonte: Vasconcellos (2018).

Verifica-se que, além de não terem sido feitos para o acesso de $P c D$, tais equipamentos têm pisos inadequados e não apresentam corrimões, demonstrando a total impossibilidade de as praias serem consideradas como passíveis de utilização por uma PcD que se desloque por meio de cadeiras de rodas ou não.

Acerca do critério piso fixo ou removível em direção ao mar, não foi constatada a presença deste item em nenhuma das praias visitadas. Ao tratar do tema, a NBR 9050 faz referências ao piso, que deve ser fixo ou removível, se prolongar em direção ao mar, com, no mínimo, 0,9om de largura, conforme a seção 10.14.2 (ABNT, 2015).

A inserção de piso para o deslocamento de cadeiras de rodas em praias é uma exceção de poucas localidades e, normalmente, só ocorre por força da realização de eventos específicos voltados para a finalidade de inclusão social de PcD em praias, tais como o Projeto Para-Praia (em Salvador, Bahia), Praia para Todos (no Rio de Janeiro, capital), Praia sem Barreiras (em Recife, Pernambuco), dentre outras cidades do Brasil. São projetos que, apesar de louváveis, em nada alteram a realidade de acessibilidade das praias envolvidas, pois, uma 
vez encerrado o evento, todos os equipamentos são retirados e o local volta a ter a mesma realidade de falta de acessibilidade de antes. ${ }^{10}$

Mais do que concretizar a realidade da absoluta falta de acessibilidade a estes espaços para PcD física, a ausência destes pisos em todas as praias visitadas faz surgir uma nova delimitação de alcance ao termo "acesso às praias" para estas pessoas, pois a elas passa a ser imposto um "quase acesso", que aqui é chamado de "usuário televisão de cachorro". ${ }^{11}$

Figura 6 - Fotografia de cães diante da máquina de assar frango ("televisão de cachorro")

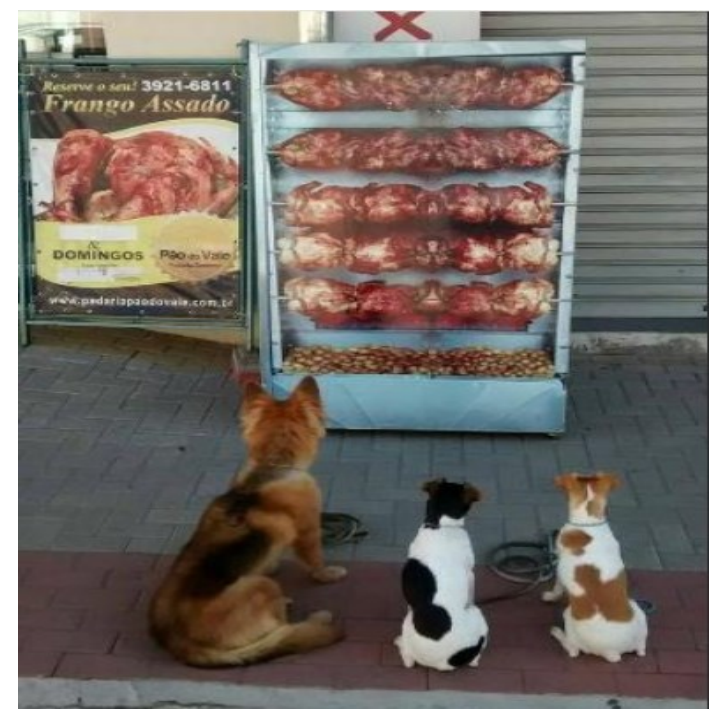

Fonte: Tripadvisor ([2017]).

Em linhas gerais, o fenômeno pode ser observado pelo seguinte exemplo: imagine-se que um cadeirante resolva ir a uma das praias de Salvador. Ao chegar ao local, deparando-se com algumas rampas, ele consiga superar a ausência dos critérios exigidos pela NBR 9050 e alcance a areia da praia. A partir deste ponto - face à ausência de piso fixo ou temporário na areia da praia, cessa seu acesso, e ele - enquanto usuário deste espaço público, passa a adotar uma conduta de mera contemplação do local, estando muito próximo da praia, porém sem

${ }^{10}$ Entretanto, destaca-se que, em algumas poucas localidades, estes equipamentos são encontrados em situação permanente, como é o caso das praias de Bertioga, Santos, Ilhabela, Guarujá e São Sebastião (todas no estado de São Paulo) e na praia do Sueste (no arquipélago de Fernando de Noronha, em Pernambuco, como afirma Garcia (2012).

${ }^{11}$ Essa é uma expressão utilizada popularmente em Salvador, reportando-se às máquinas de assar frango expostas em frente às lojas, diante das quais os cachorros ficam sentados, contemplando os assados, mas sem nunca ter acesso ao que contemplam. 
nunca ter efetivo acesso àquele espaço (tal qual os cachorros para com a máquina de assar frangos).

Despiciendo comentar que "acesso à praia" não se limita a passear pelo seu entorno ou alcançar o limiar do início da areia, mas sim, o pleno usufruto do espaço público que, neste caso, é a própria praia. Por tal razão, a falta de acessibilidade das praias de Salvador para PcD física contribui para caracterizar aquelas pessoas que resumem sua utilização de bens públicos a um "quase-acesso" ao bem, ou a um acesso parcial, até certo ponto.

Apesar da realidade de absoluta falta de acessibilidade nas praias visitadas, quase $70 \%$ das PcD físicas investigadas declararam que frequentam estes locais. Diante destes dados, sobre os quais prevalece a não frequência face à falta de acessibilidade, uma segunda indagação restou inevitável: o que estas pessoas compreendem como "frequentar praias?".

Figura 7-Gráfico das respostas da pesquisa de opinião envolvendo PCD física quanto a se frequentam ou não as praias

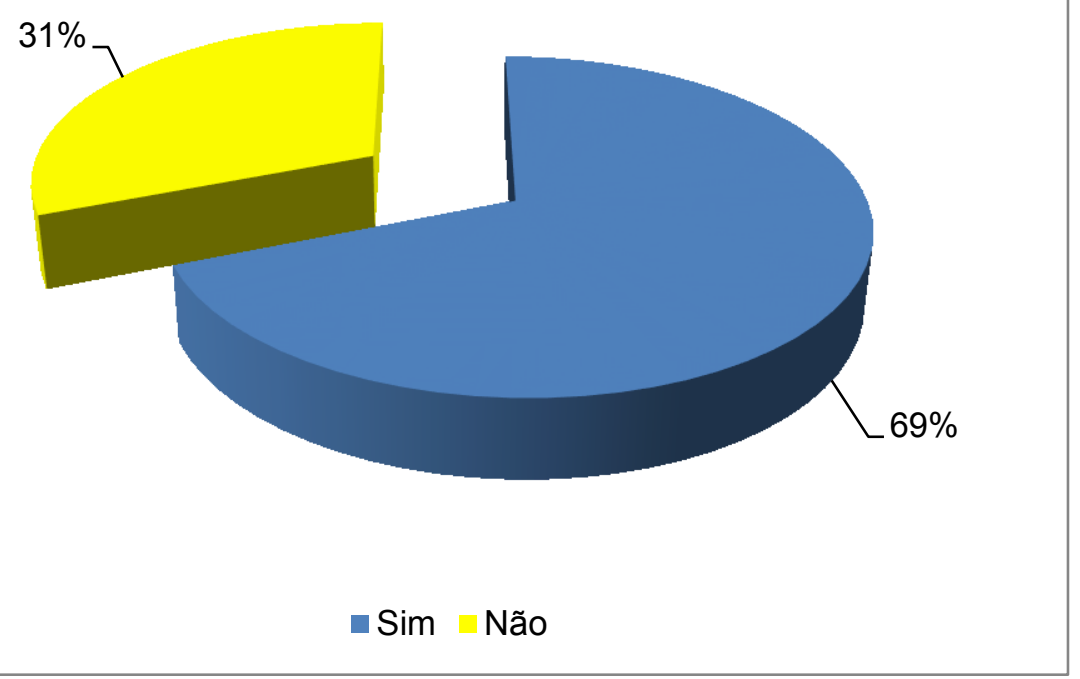

Fonte: pesquisa de campo.

Somado a este surpreendente percentual, mais de 90\% dos participantes da pesquisa informou que ainda que não consideram as praias de Salvador acessíveis, gerando uma inquietação ainda maior, pois se indaga como eles frequentam estas praias se elas não são acessíveis? 
Figura 8 - Gráfico das respostas quanto às opiniões de PcD física sobre se acham, ou não, que as praias de Salvador são acessiveis

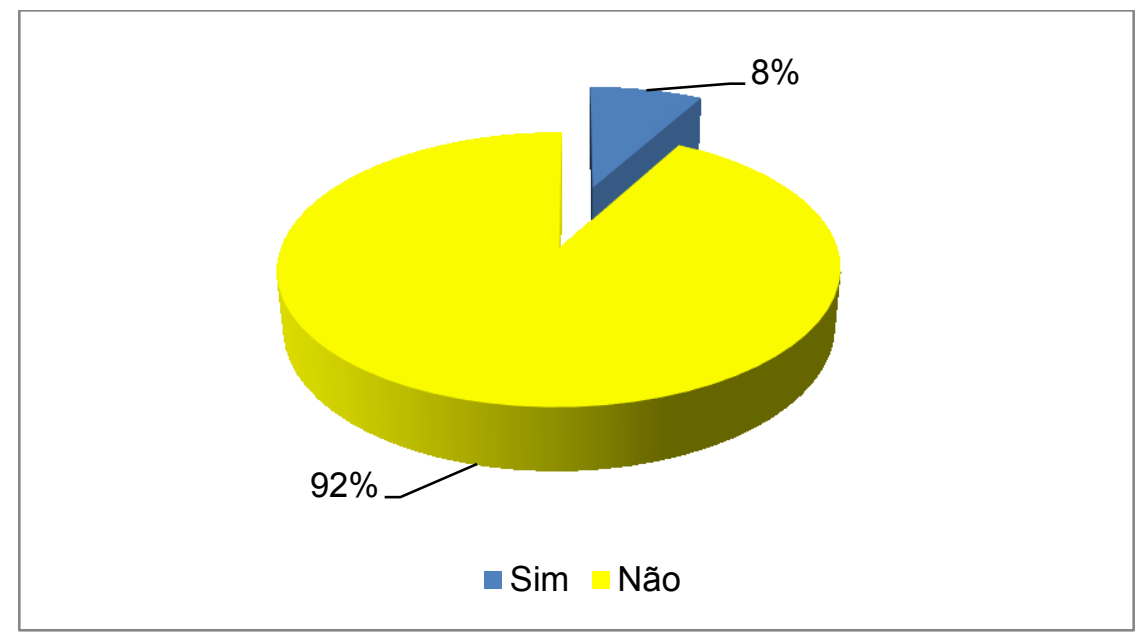

Fonte: pesquisa de campo.

Diante dos dois números oriundos do questionário aplicado às $\mathrm{PCD}$ investigadas, somando-se ao fato do fenômeno da acessibilidade formal e o "quase acesso" citado alhures, preponderantes para a realidade das praias de Salvador, constatou-se que a noção de acesso às praias para estas pessoas não é a mesma que comumente se costuma ter. Nesse sentido, para as PcD física, a frequência à praia significa chegar e estar nas calçadas, parques ou demais áreas anexas ao efetivo espaço da praia, onde se reúnem para conversar com amigos e familiares ou fazer passeios, como pôde ser constatado nas praias da Ribeira, Barra e Boca do Rio (Armação).

Figura 9 - Fotografia de PcD física conversando com familiares na calçada da praia da Penha (na Ribeira)

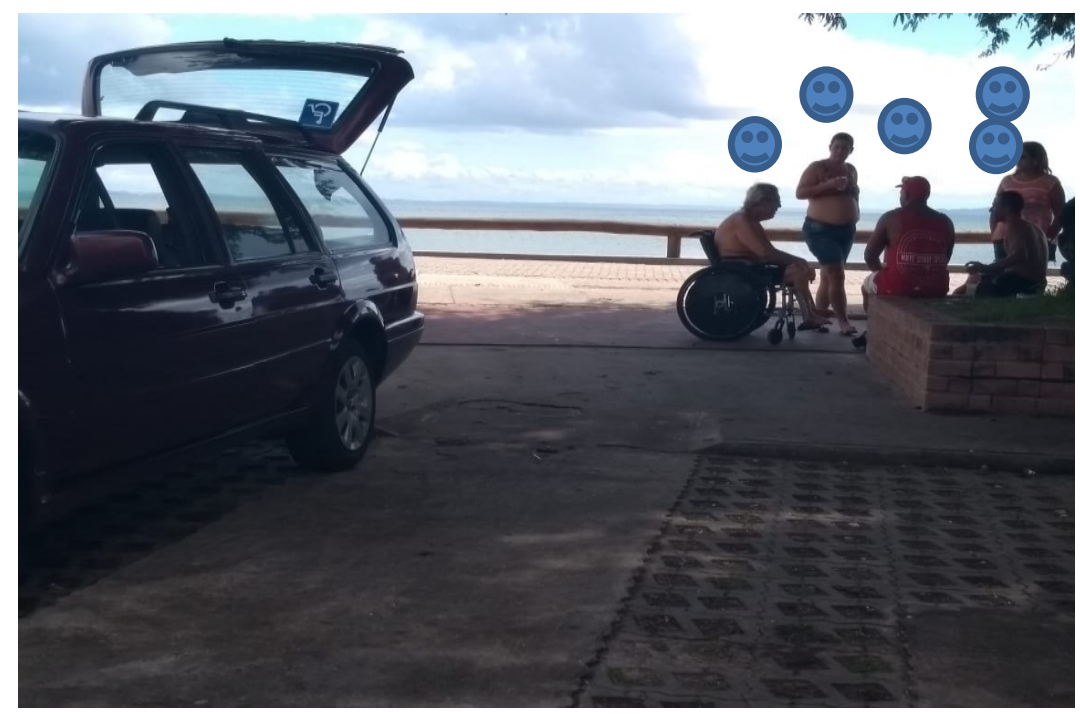

Fonte: Vasconcellos (2018s). 
O terceiro elemento citado pela norma técnica de acessibilidade - o Símbolo Internacional de Acesso (SIA) -, foi identificado em apenas algumas das 12 praias visitadas e, mesmo assim, para indicar, apenas, estacionamentos com vagas reservadas às $\mathrm{PcD}$, e não locais acessíveis como banheiros e rampas.

Figura 10- SIA

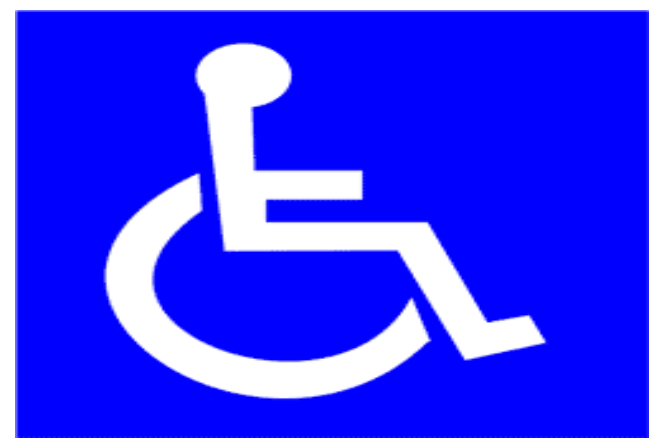

Fonte: ABNT (2015, p. 39).

A presença do SIA expressa a representação de local acessível, assim compreendido de acordo com a NBR 9050 -, como a possibilidade e condição de alcance, percepção e entendimento para a utilização, com segurança e autonomia, de "[...] espaços, edificações, mobiliário e equipamentos urbanos, onde existem elementos acessíveis ou utilizáveis por pessoas com deficiência ou com mobilidade reduzida." (ABNT, 2015, p. 39).

Em outras palavras, o SIA apenas poderá ser utilizado nos locais efetivamente acessíveis e não naqueles em que exista apenas uma rampa ou uma eventual vaga reservada para PcD e, dessa forma, ironicamente, a ausência deste símbolo nas praias visitadas é correta.

Destaca-se, porém, que o fato de o símbolo ter sido identificado em algumas praias para indicar a reserva de vagas para $\mathrm{PCD}$, isso não se deu pelo cumprimento às normas de acessibilidade - pois os espaços visitados não eram acessíveis -, mas sim, por força da Lei 10.098/00, que é regulamentada pela Resolução n. 304, de 18 de dezembro de 2008, do Conselho Nacional de Trânsito (CONTRAN), que se refere às vagas de estacionamento reservadas para PcD (BRASIL, 2000, 2008). ${ }^{12}$

\footnotetext{
${ }^{12}$ Ademais, o art. 181, inciso XX da Lei 9.503/97 - Código de Trânsito brasileiro -, estabelece uma infração administrativa passível de multa e remoção do veículo para aqueles que estacionam nestas vagas sem a
} 
Em outras palavras, além de não indicarem espaços acessíveis, tais placas em praias têm sua razão de ser, não por imperativos das normas de acessibilidade, mas sim, por medo de aplicação de multas decorrentes da norma de trânsito, afinal, todas as placas citadas foram encontradas em estacionamentos e não em outros locais.

Por fim, quanto ao quarto e último requisito, indica-se a existência de sanitários unissex acessíveis, os quais, nos termos da norma técnica, para serem considerados acessíveis, devem apresentar no mínimo três elementos básicos: a) área de transferência ${ }^{13}$; b) bacia sanitária em dimensões específicas e c) barras de apoio (ABNT, 2015).

Para a realidade dos espaços urbanos externos, dentre os quais as praias estão inseridas, é comum a utilização de sanitários químicos, os quais devem - de igual forma -, obedecer aos requisitos indicados acima, sendo necessária uma cabine maior do que as usualmente utilizadas, de forma a se respeitar o primeiro dos elementos indicados (área de transferência).

Na Figura 42, tem-se um exemplo das dimensões físicas de um sanitário químico voltado à PcD que necessite usar cadeiras de rodas, no qual é possível perceber, por simples aferição visual - quando comparado com as cabines para pessoas sem deficiência -, que a cabine de banheiro para $\mathrm{PcD}$ que se deslocam por meio de cadeiras de rodas tem uma dimensão maior, sendo de mesma altura, porém, mais larga, justamente para assegurar a área de transferência.

credencial devida (BRASIL, 1997). Ora, para o Estado multar, é preciso primeiro definir quais vagas não podem ser utilizadas.

13 Segundo a NBR 9050 (seção 4.4), considera-se área de transferência o espaço necessário para que uma pessoa, utilizando cadeira de rodas, possa se posicionar próximo ao mobiliário para o qual necessita transferirse (BRASIL, 2015). 
Figura 11 - Fotografia de uma cabine de sanitário químico para PcD

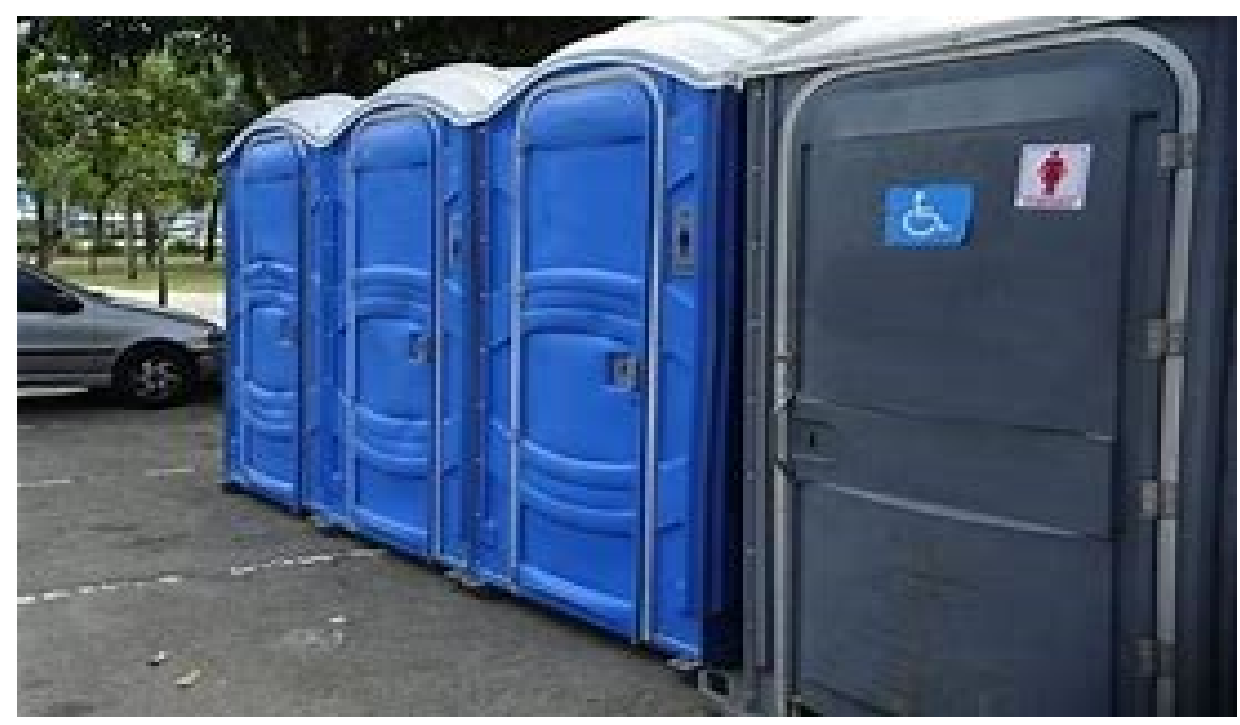

Fonte: Frazão (2015).

Por fim, acerca do terceiro requisito indicado, as barras de apoio utilizadas em sanitários devem apresentar diâmetro entre 3 e 4,5cm, além de ser fixadas de forma segura e a uma distância mínima destas de $4 \mathrm{~cm}$ da face interna da barra (ABNT, 2015).

Quanto à forma, a norma técnica ainda exige que, em suas extremidades, estas barras sejam fixadas em desenvolvimento contínuo e em formato recurvado, conforme se pode visualizar na Figura 12:

Figura 12 - Desenho esquemático da disposição de barras de apoio ao fundo e a $90^{\circ}$ na parede lateral em sanitários para PcD física

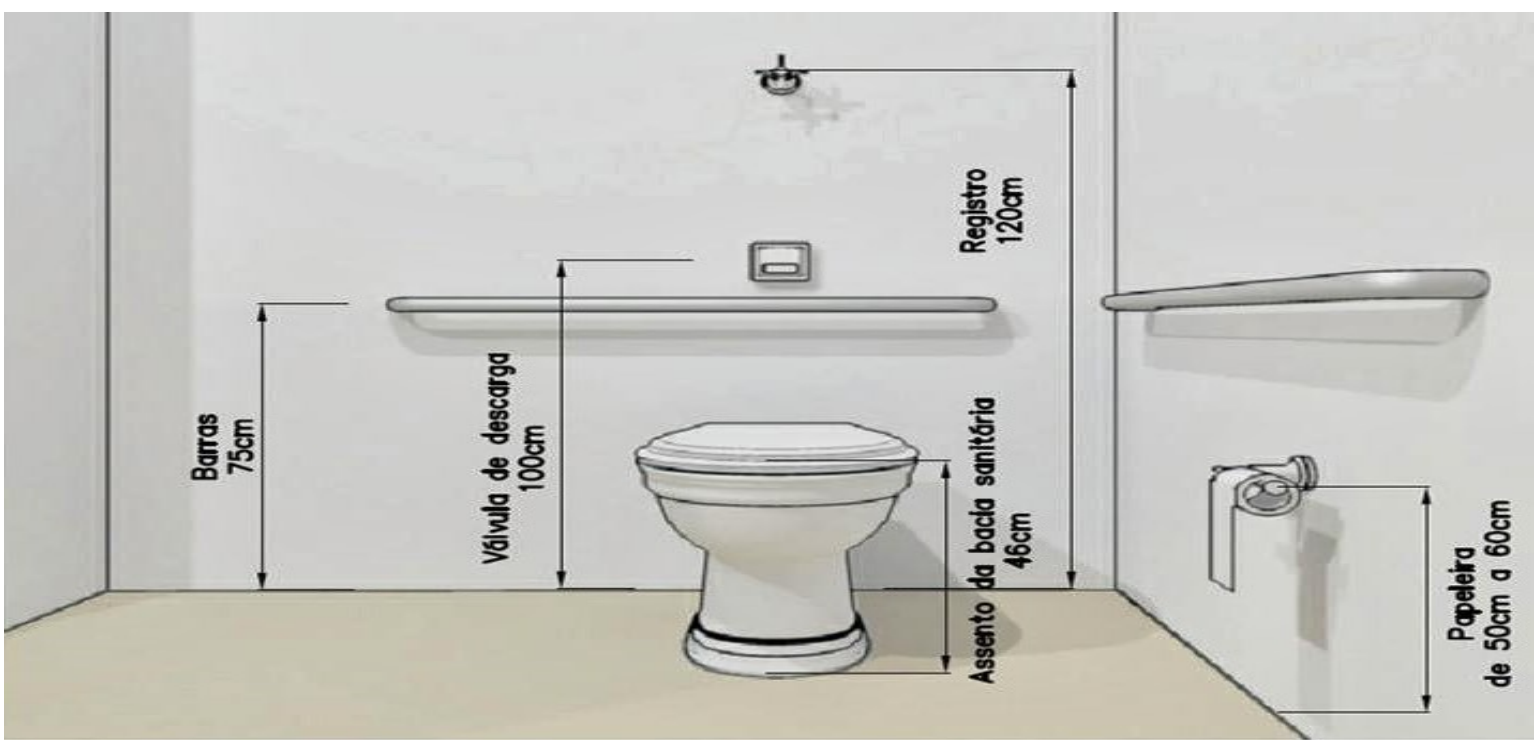

Fonte: ABNT (2015, p. 92-93). 
Em nenhuma das 12 praias visitadas foram identificadas cabines com barras de apoio ou mais alargadas (como na Figura 12), restando a utilização das cabines de tamanho padrão utilizadas pelos usuários que não possuem nenhuma limitação. ${ }^{14}$

Para além de não terem sido encontradas tais cabines em condições de uso, foi verificado que, em muitas delas, tais equipamentos eram inseridos em locais inapropriados, obstruindo a livre circulação de cadeirantes, tal como foi registrado nas praias da Ribeira ou São Tomé (Paripe), conforme pode ser demonstrado nas Figuras 13 e 14 a seguir:

Figura 13 - Fotografia de cabines de sanitários químicos bloqueando o acesso de PcD física à calçada na praia da Ribeira

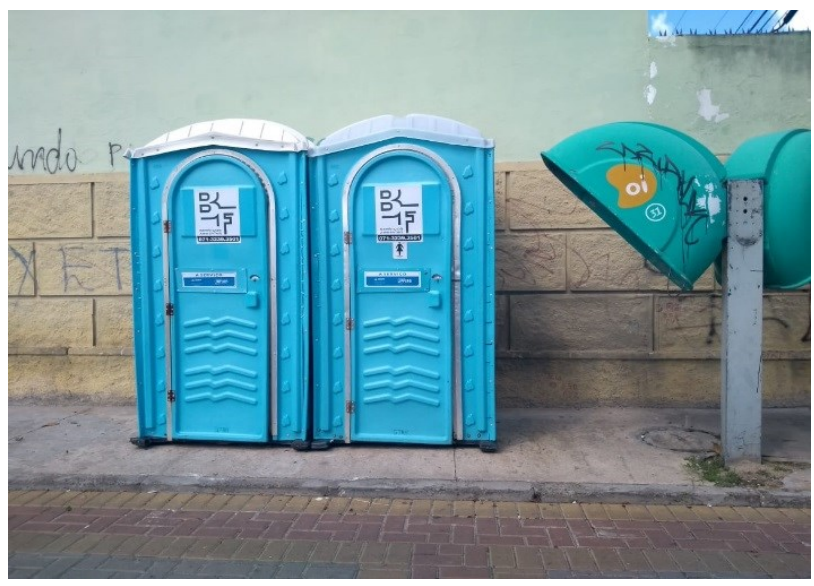

Fonte: Vasconcellos (2018).

No caso ilustrado pela Figura 13, a colocação indevida destas cabines é agravada pelo fato da existência de um telefone público logo a seguir, bloqueando, em absoluto, o livre acesso de cadeirantes ao local e, até mesmo, o acesso a tais cabines por estes, pois o espaço restante à frente do equipamento é insuficiente para o livre acesso frontal e à movimentação de cadeirantes, violando-se a primeira das condições da norma técnica já citada alhures, qual seja, a área de transferência.

Esta situação se repete em várias das 12 praias visitas e, além da Ribeira, na praia de São Tomé (em Paripe), a inserção do equipamento é também equivocada e bloqueia o acesso absolutamente de todos os usuários (e não apenas PcD).

\footnotetext{
${ }^{14}$ Porém, considerando-se que o universo de PcD não se resume apenas a cadeirantes, tais cabines foram passíveis de uso para fins deste trabalho, haja vista serem utilizadas pelas demais PcD física, como as que utilizam muletas ou bengalas.
} 
Figura 14 - Fotografia de cabines de sanitários químicos na praia de São Tomé (em Paripe)

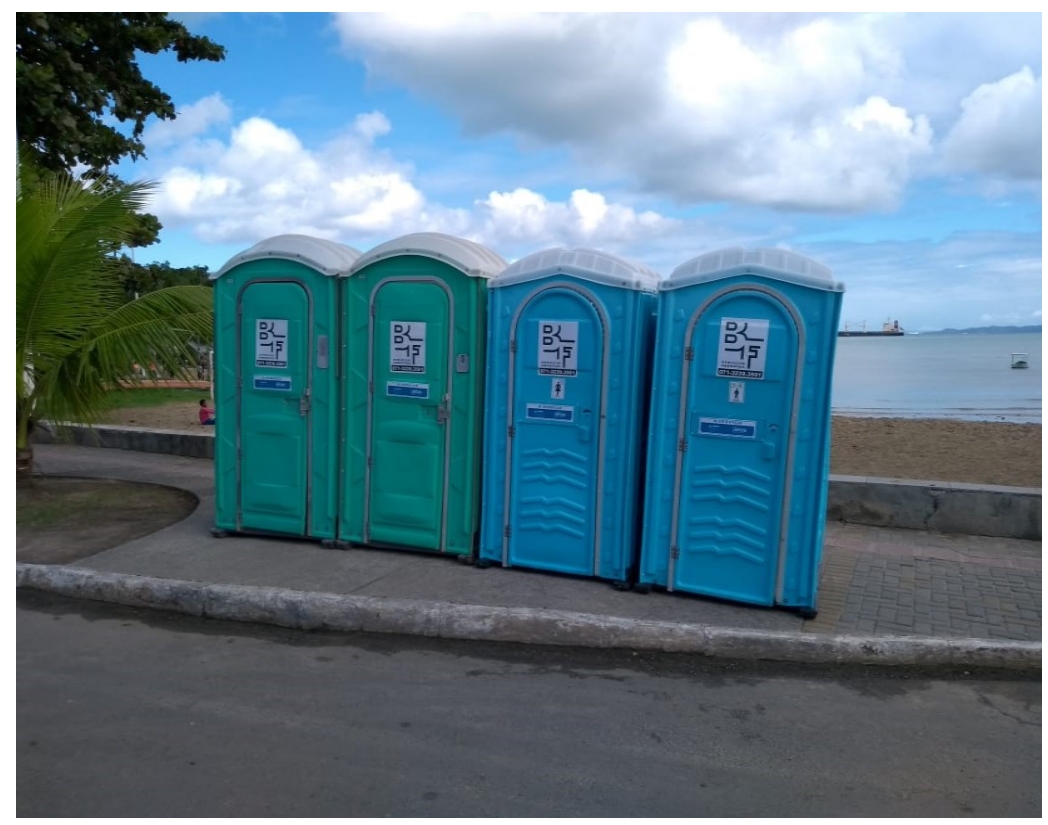

Fonte: Vasconcellos (2018b).

Na Figura 14, apesar de haver certo espaço atrás das cabines, estas foram organizadas em posição diagonal ao piso (conforme se pode observar aferindo-se a distância entre elas e o meio fio à frente), bloqueando o livre acesso de cadeirantes pela calçada.

Em síntese, enquanto fruto da observação direta realizada nestas 12 praias visitadas, pode-se afirmar que não existe acessibilidade nestes locais, sendo os equipamentos existentes de pouca ou nenhuma serventia para $P c D$, representando uma acessibilidade meramente formal, o que justifica o fato de, no período das visitas às praias, terem sido encontradas poucas PcD física nestes espaços, apesar das declarações coletadas indicarem que as PCD frequentam as praias como opção de lazer.

\section{Conclusões}

Ao se considerarem os objetivos estabelecidos, já na primeira parte, foi demonstrado que a compreensão da deficiência tem um caráter histórico, tendo evoluído de uma noção até o início do Século XX-, quando era compreendida como um tipo de disfunção do corpo, um tipo de patologia (no modelo biomédico), até a noção em que passa a ser compreendida - no início do Século XX aos dias atuais, como um atributo do próprio corpo (no modelo social). Fruto destas distintas noções trazidas pelos modelos citados, constatou-se que estas possuem reflexos distintos para a responsabilidade estatal, prevalecendo um caráter 
exoneratório de responsabilidade no âmbito do paradigma do modelo biomédico e um caráter inclusivo de responsabilidade estatal e da sociedade no modelo social. Afinal, sendo a deficiência um atributo comum ao corpo da pessoa, Estado e sociedade passam a ter responsabilidade direta pela inclusão, protegendo e efetivando direitos básicos de cidadania das $P C D$, dentre os quais se insere o acesso às praias.

Aferindo, especificamente, a realidade do nível de acessibilidade das praias de Salvador para PCD física, tendo como parâmetros os requisitos de acessibilidade estabelecidos pela NBR 9050, constatou-se que não existe acessibilidade para PCD nas referidas praias, fato que foi corroborado pela aferição dos quatro requisitos exigidos pela NBR 9050 para a compreensão de acessibilidade de espaços públicos externos: a) rampas; b) piso fixo ou removível em direção ao mar, c) banheiros acessíveis e d) acessos devidamente sinalizados por meio do símbolo internacional de acesso.

Mais do que concluir que não existe acessibilidade às praias de Salvador face à falta de cumprimento destes requisitos, foi possível identificar problemas a partir de cada um deles: quanto ao primeiro, constatou-se que prevalece a existência de rampas sem o cumprimento dos critérios exigidos pela norma técnica, com equipamentos inapropriados e que trazem insegurança para quem deles faz uso. Além disso, ficou constatado que, em algumas praias, há rampas improvisadas, criadas para o uso dos pescadores, porém também utilizadas por PcD de forma inapropriada.

Quanto ao segundo requisito, foi constado que inexiste piso fixo ou removível em direção ao mar, sendo que esta ausência delimita o nível máximo de acesso que as PcD têm a estes espaços, gerando o fenômeno do usuário "televisão de cachorro", uma vez que estas pessoas (ao menos os cadeirantes) têm seu alcance máximo até onde a rampa os permite alcançar, ou seja, no limiar da areia da praia. Deste ponto em diante, adota-se apenas uma postura de contemplação do mar, sem nunca ter acesso ao espaço efetivo da praia.

Com tal fenômeno, constatou-se que, apesar de uma grande maioria afirmar que frequenta as praias e reconhecerem estes espaços como uma boa opção de lazer, a noção de frequência e acesso feita por essas pessoas é específica e bastante restrita, uma vez que se limitam a frequentar áreas do entorno da praia (calçadas, praças anexas e outros espaços próximos) onde podem ficar com amigos e/ou familiares conversando, bebendo e confraternizando, sem, contudo, terem acesso efetivo aos espaços das praias. 
O descumprimento do terceiro requisito - os sanitários acessíveis - é caracterizado pela ausência de cabines de banheiros químicos adaptadas, repercutindo no fenômeno da acessibilidade meramente formal, sendo que estes equipamentos - além de imprestáveis para PcD que usam cadeiras de rodas, face às dimensões equivocadas do equipamento e à falta de barras de apoio -, trazem óbices à mobilidade de cadeirantes, pois, em muitos casos, são localizadas em pontos não adequados da calçada, criando obstáculos à livre circulação destas pessoas.

Quanto ao quarto e último requisito - a existência de utilização do SIA para sinalizar espaços acessíveis -, constatou-se que sua ausência em todas as praias visitadas reforça o estado de inacessibilidade para $\mathrm{PcD}$, sendo, como exceção, encontrado este símbolo apenas por ocasião da indicação de vagas reservadas à PcD nos estacionamentos das praias visitadas. Tais placas foram justificadas devido à exigência de normas de trânsito e não ao cumprimento às normas de acessibilidade de espaços públicos.

Ante o quadro geral de descumprimento dos requisitos indicados pela NBR 9050, e considerando-se o problema de pesquisa suscitado na introdução deste trabalho, conclui-se que, apesar das últimas políticas públicas voltadas à urbanização da orla, estas foram absolutamente omissas quanto à acessibilidade às praias para PCD física, não existindo, assim, em termos absolutos, acessibilidade para as PCD física nas praias de Salvador, sendo que a frequência destas pessoas a estes espaços ocorre de forma muito específica e limitada às calçadas, aos parques próximos e às demais áreas do entorno do efetivo espaço da praia, reflexo do fenômeno aqui denominado de "usuário televisão de cachorro", expressando a negação à condição cidadã destas pessoas, mesmo em pleno paradigma inclusivo gerado pelo modelo social de deficiência.

\section{Referências}

ALBUQUEROUE, Luciana Maria Cabral Gomes de. Identificação de problemas de acessibilidade e melhoria da qualidade de vida dos usuários que frequentam o projeto "Praia Sem Barreiras" em Boa Viagem-PE. 2015. 148 f. Dissertação (Mestrado em Ergonomia) - Universidade Federal de Pernambuco, Recife, 2015. Disponível em: http://repositorio.ufpe.br/handle/123456789/16734. Acesso em: 16 jul. 2017.

AMIRALIAN, Maria L. T. et al. Conceituando deficiência. Revista de Saúde Pública, São Paulo, v. 34, n. 1, p. 97-103, fev. 2000. Disponível em: http://www.scielo.br/pdf/rsp/v34n1/1388.pdf. Acesso em: 16 jul 2017. 
ASSOCIAÇÃO BRASILEIRA DE NORMAS TÉCNICAS (ABNT). NBR 9050. Acessibilidade a edificações, mobiliário, espaços e equipamentos urbanos. Rio de Janeiro, 2015. Disponível em: http://www.ufpb.br/cia/contents/manuais/abnt-nbrg050-edicao-2015.pdf. Acesso em: 16 jul. 2017.

BARBOSA, Jaque. Praias do Nordeste criam estrutura inovadora para receber deficientes físicos. [S.I.]: Hypeness, [2013]. Disponivel em: https://www.hypeness.com.br/2013/12/iniciativa-nonordeste-permite-a-deficientes-fisicos-se-refrescarem-no-mar/. Acesso em: 30 jun. 2017.

BRETON, David Le. Adeus ao corpo. 3. ed. São Paulo: Papirus, 2003.

CARVALHO, Inaiá Maria Moreira de; PEREIRA, Gilberto Corso. As "cidades" de Salvador. In: CARVALHO, Inaiá Maria Moreira de; PEREIRA, Gilberto Corso (org.). Como anda Salvador e sua

Região Metropolitana. 2. ed. rev. e ampl. Salvador: EdUfba, 2008. p. 81-108. Disponível em: https://repositorio.ufba.br/ri/bitstream/ri/1724/1/Como\%2oanda\%2oSalvador_RI.pdf. Acesso em: 28 dez. 2017.

CARVALHO-FREITAS, Maria Nivalda de. A inserção de pessoas com deficiência em empresas brasileiras: um estudo sobre as relações entre concepções de deficiência, condições de trabalho e qualidade de vida no trabalho. 2007. 314 f. Tese (Doutorado em Administração) - Universidade Federal de Minas Gerais, Belo Horizonte, 2007. Disponível em: https://ufsj.edu.br/portal2repositorio/File/incluir/tese_maria_nivalda.pdf. Acesso em: 28 dez. 2017.

COHEN, Regina. Cidade, corpo e deficiência: percursos e discursos possíveis na experiência urbana. 2006. 213 f. Tese (Doutorado em Psicossociologia de Comunidades e Ecologia Social) - Programa de Estudos Interdisciplinares de Comunidades e Ecologia Social, Universidade Federal do Rio de Janeiro, Rio de Janeiro, 2006. Disponível em: http://docplayer.com.br/426919o8-Cidade-corpo-edeficiencia-percursos-e-discursos-possiveis-na-experiencia-urbana.html. Acesso em: 12 jul. 2018.

CUYÁS, Enrique Rovire-Beleta. Acessibilidade em instalações esportivas. In: LICHT, Flavia Boni; SILVEIRA, Nubia (org.). Celebrando a diversidade: pessoas com deficiência e direito à inclusão. São Paulo: Planeta Educação, 2010. p. 223-232. Disponível em:

http://www.faders.rs.gov.br/uploads/1349101635Celebrando_Diversidade.pdf. Acesso em: 28 dez. 2017.

DINIZ, Debora. O que é deficiência. São Paulo: Brasiliense, 2007. Disponível em:

https://pedagogiafadba.files.wordpress.com/2013/03/texto-1-o-que-czag-deficiczaancia.pdf. Acesso em: 28 dez 2017.

DISCHINGER, Marta; ELY, Vera Helena Moro Bins; PIARDI, Sonia Maria Demeda Groisman.

Promovendo acessibilidade espacial nos edifícios públicos: programa de acessibilidade às pessoas com deficiência ou mobilidade reduzida nas edificações de uso público. Florianópolis: MPSC, 2012. Disponivel em: http://docplayer.com.br/7230292-Promovendo-acessibilidade-espacial-nos-edificiospublicos.html. Acesso em: $28 \mathrm{dez} 2017$.

DUARTE, Cristiane Rose de Siqueira; COHEN, Regina. Acessibilidade para todos: uma cartilha de orientação. Rio de Janeiro: Núcleo Pró-Acesso; UFRJ/FAU/PROAQRG, 2004.

FRAZÃO, Fernando. Cabine de banheiro químico para PcD no entorno do complexo da Lagoa, na cidade do Rio de Janeiro. Agência Brasil, Rio de Janeiro, 04 set. 2015. 1 Fotografia. Disponível em: http://agenciabrasil.ebc.com.br/geral/noticia/2015-09/aplicativo-registra-falta-de-acessibilidade-nalagoa-para-paralimpiadas. Acesso em: http://agenciabrasil.ebc.com.br/geral/noticia/2015-

og/aplicativo-registra-falta-de-acessibilidade-na-lagoa-para-paralimpiadas. Acesso em: 28 dez. 2017.

GARCIA, Vera. Cadeira de rodas que entra no mar chega a mais 5 cidades de São Paulo. Deficiente Ciente, [s.l.], 02 jan. 2012. Disponível em: https://www.deficienteciente.com.br/cadeira-de-rodasque-entra-no-mar-chega-a-mais-5-cidades-de-sp.html. Acesso em: 15 maio 2018. 
INSTITUTO BRASILEIRO DE GEOGRAFIA E ESTATÍSTICA (IBGE). Pesquisa Nacional de Saúde: 2013 - acesso e utilização dos serviços de saúde, acidentes e violências - Brasil, grandes regiões e unidades da federação. Rio de Janeiro, 2015. Disponível em:

https://biblioteca.ibge.gov.br/visualizacao/livros/liv94074.pdf. Acesso em: 23 maio 2018.

INSTITUTO BRASILEIRO DE GEOGRAFIA E ESTATÍSTICA (IBGE). Salvador. [Rio de Janeiro], 2017. Disponível em: https://cidades.ibge.gov.br/brasil/ba/salvador/panorama. Acesso em: 23 maio 2018.

MINISTÉRIO DA SAÚDE. Conselho Nacional de Saúde (CNS). Resolução n. 466, de 12 de dezembro de 2012. Diário Oficial da União, Brasília, DF, n. 12, p. 59, 13 jun. 2013. Disponível em:

http://conselho.saude.gov.br/resolucoes/2012/reso466.pdf. Acesso em: 28 dez. 2017.

PIOVESAN, Flavia. Temas de Direitos Humanos. 3. ed. São Paulo: Saraiva, 2009.

PONTES, Taís Furtado. Avaliação da mobilidade urbana na área metropolitana de Brasília. 2010. 249 f. Dissertação (Mestrado em Arquitetura e Urbanismo) - Universidade de Brasília, Brasília, DF, 2010. Disponível em:

http://repositorio.unb.br/bitstream/10482/7789/1/2010_TaisFurtadoPontes.pdf. Acesso em: $1^{\circ}$ jan. 2018.

RIBAS, João Batista Cintra. O que são pessoas deficientes. São Paulo: Nova Cultural, Brasiliense, 1985. Coleção Primeiros Passos.

SANDES, Jessica. Projeto para-praia começa na orla de Ondina. Jornal A Tarde, Salvador, 03 jan. 2015. Caderno Bahia-Salvador. Disponível em:

http://atarde.uol.com.br/bahia/salvador/noticias/1650205-projeto-para-praia-comeca-na-orla-deondina. Acesso em: 30 maio 2018.

SANTOS, Paulo Roberto Neves. Intervenções urbanísticas em Salvador e o direito à cidade das pessoas com Deficiência: o caso da Avenida Centenário. 2012. 193 f. Dissertação (Mestrado em Arquitetura e Urbanismo) - Universidade Federal da Bahia, Salvador, 2012. Disponível em: https://repositorio.ufba.br/ri/bitstream/ri/13073/3/Dissertação_Paulo\%2oRoberto\%2oNeves\%20San tos.pdf. Acesso em: 30 mar. 2018.

SOUSA JUNIOR, Francisco Rodrigues de; FLORO, Elisângela Ferreira. Acessibilidade e envelhecimento: análise de calçadas e passeios públicos no município de Juazeiro do Norte. Revista Científica Multidisciplinar Núcleo do Conhecimento, 6. ed., ano 2, v. 1, set. 2017. Disponível em: https://www.nucleodoconhecimento.com.br/educacao/acessibilidade-e-envelhecimento. Acesso em: 06 out. 2018.

SOUZA, Eron Bispo de. Planejamento e gestão da orla de Salvador-Bahia. 2017. 316 f. Dissertação (Mestrado em Geografia) - Universidade Federal da Bahia, Salvador, 2017. Disponível em: https://repositorio.ufba.br/ri/bitstream/ri/24728/1/DISSERTAÇAO_ERON_BISPO_DE_SOUZA_FINA L.pdf. Acesso em: 27 mar. 2018.

\section{Dados do autor}

Milton Silva de Vasconcellos

Mestre em Políticas Sociais e Cidadania UCSAL (2019). Especialista em Direito Público/Nassau (2010) Bacharel em Direito pela Faculdade Baiana de Ciências (2009). Bolsista da FAPESB (2017-2018), integrante do Grupo de Estudos e Pesquisa sobre Trajetórias Participativas e Políticas Sociais (UFRB). Professor universitário (graduação e pós-graduação) da Faculdade UNIFASS. E-mail: miltonsvasconcellos@gmail.com 